\title{
Missional fatherhood as a strategy to inmates who struggle with father absence: Building hope through a programme
}

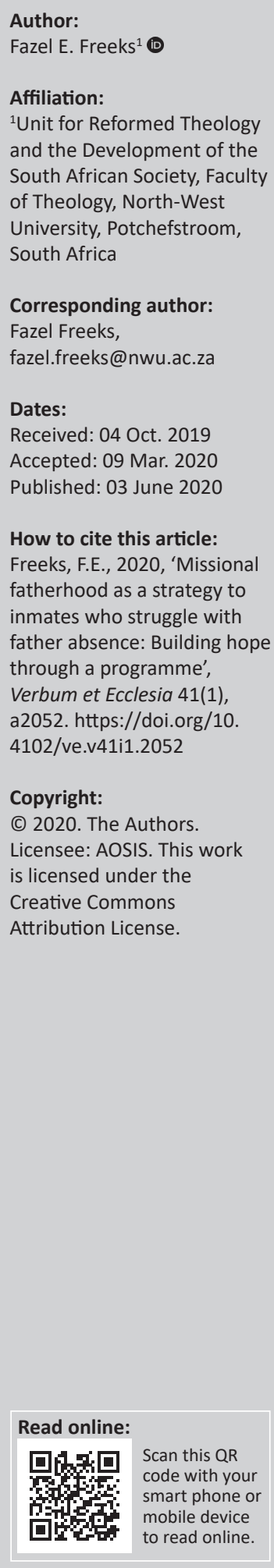

Families remain the world's oldest, most basic form of relationship. However, in the 21st century, this unit is facing multiple crises. The fact cannot be ignored that many families experience no fatherly presence. This lack is a contributing factor to children in need of care and protection in South Africa. The Children's Act 38 of 2005 stipulates that a child in need of care and protection is the child who face any social issue such as abuse and absent parents and who abuse alcohol, drugs and other substances. Currently, there are a seemingly endless number of activities outlined for the family. However, these activities are insignificant when measured against God's plan for families.

Intradisciplinary and/or interdisciplinary implications: Father absenteeism and fatherlessness lead to many families and, especially, children destroyed. The family is redefined, and significantly, the father does not feature in this definition. Missional fatherhood has an interdisciplinary approach comprising two disciplines: missiology and practical theology. Missional fatherhood implies to live sacrificial lives for the sake of families and children, and cater for the needs of others. Missional fathers are committed to a God-given mission where fathers model and inculcate the love of Christ into the hearts of their children.

Keywords: missional; fatherhood; inmates; families; father absence; hope; training; equipping; programme.

\section{Introduction and problem statement}

Colonisation and urbanisation were major factors that transformed family arrangements extensively in the 20th century in South Africa, not to mention the roles that parents played, especially the crucial one of the father pertaining to fatherhood (Richter, Chikovore \& Makusha 2010:361-362). However, fatherhood has changed over time, and as a result, most families are struggling with serious problems and challenges in their respective communities such as unemployed youth, poor school performance, teenage pregnancy, substance abuse, human immunodeficiency virus and acquired immunodeficiency syndrome (HIV/AIDS) and gangsterism (Linn, Wilson \& Fako 2015:12-13). Presently, one of these more serious problems in family life is the issue of father absenteeism (and dysfunctional families). Dysfunctional family life is a major social issue with fatherlessness forming the core problem. Men do not seem to realise the crucial role they play within the family as fathers, and this is one of the most harmful demographic trends of the present generation and the main reason for the increase in child welfare projects. The epidemic of absent fathers is a causal factor of the urgent social problems such as teenage pregnancy, child abuse, neglect and domestic violence or crime, and many more factors.

A pattern has emerged where social pathologies have been linked to father absenteeism and fatherlessness. Children, for example, who grew up in a household with an absent father, do not have an example of what it means to be a true father themselves (Meintjies \& Hall 2013). This pattern gets repeated from generation to generation in that absent and even abusive fathers themselves had no role model of paternity, to raise their own children. Statistically, families and society at large cannot escape the painful truth that there is a fatherhood 'disease' in the world. This problem of fatherlessness is defining a lost generation of children (The Herald 18 April 2002:8).

As pointed out by Trethowan (2008:21-24), for generations, children have been informally cared for by communities and families within societies. In so doing, societies have created a concept of 
coming together to use their 'village to raise a child' (Tyatya 2015). Because the father figure plays an enormous role in the social functioning of families and, more specifically, children, it is of the utmost importance for communities to be more vigilant in terms of the significance of the father figure from a social and biblical perspective with Christian families as the centre of the argument:

The father is accountable before God to lead his family with sacrificial love ... children understand the concept of God better if they understand their earthly or physical father ... the father has to demonstrate a godly character and he must be a follower of Christ and must reveal certain characteristics such as humbleness, softness of heart and patience towards his children (2 Tm 2). (Freeks 2008)

In 2012, South Africa was rated as one of the countries in the world with the highest figures of father absenteeism (Freeks 2016; Richter et al. 2012). Therefore, it is not surprising that this is one of the leading causes of the breakdown of family life (Bertelsmann 2016). This neglect of fatherhood within South African society can be traced by to the beginning of the 21st century (Ratele, Shefer \& Clowes 2012:553-563).

In many cases, the term 'family' is redefined, and significantly, the father does not even feature in this definition (Ford et al. 2008:284-299). From a biblical point of view, this problem originated with the fall of humans into sin which resulted in a cycle of problems caused by fathers who do not fulfil their God-given role within the family unit (Gn 3:1-24). Colonialism was one of the major problems of this redefinition and disrupted families.

Although South African fathers do not differ that much from fathers elsewhere, South Africa has unique circumstances that impact families. For example, during the era of the migrant labour system caused by colonialism as mentioned earlier, families were disrupted, split and separated because fathers had to leave their immediate family and work in the mines and cities, only returning home over the Christmas period (Frazier 2019).

In Africa after Namibia, South Africa has the second highest rate of father absenteeism (Richter et al. 2010:360), and to compound matters, this rate is on the increase in the South African context. This tendency, in turn escalated, generates problems such as broken families, aggressive behaviour amongst children, as well as financial and social ills, and poverty (cf. Bartlett 2013; Freeks 2016:2).

Father absence is a desperate cry for help and a deep concern as many households are run by single mothers (Amoateng et al. 2004; The Herald 18 April 2002:8). This matter is farreaching and worrying as statistics revealed that $31 \%$ of mothers are raising their babies without a father figure. Furthermore, 1.1 million births were registered in 2015, of which $64 \%$ indicated that information about the biological father is lacking. Such cases eventually result in single parenting, and significantly for this article, single parenting in South Africa is the leading cause of the fatherhood problem. In 2015, an estimated 886202 babies were born, and $50 \%$ of the women who gave birth were single mothers with no assistance from the biological fathers (Hawkins 2015).

Another devastating problem of children growing up without fathers in South Africa is the fact that $5.3 \mathrm{~m}$ of these children are younger than 5 years, for whom both parents (93\%) are alive. These children comprise approximately $10 \%$ of the population and many live in adverse conditions (of poverty) as a result of fatherlessness (Mkhize 2013:2). While it is to be assumed that fatherhood is paramount for all races in society, when comparing statistics between the different races, an even grimmer picture emerges. Approximately 33\% - 38\% of black children lived with their fathers, and $79 \%$ with their mothers, compared to the $87 \%$ of white children who lived with their fathers (Mkhize 2013).

The increasing number of absent fathers has become not only a dilemma but caused a serious debate within South Africa. In 2010, the South African Institute of Race Relations released statistics indicated that $56 \%$ of divorces were by parents with children and that $48 \%$ of these children have no fathers. This resulted in a total of $3.95 \mathrm{~m}$ orphans, yet another disturbing trend on the increase in South Africa (Frazier 2019). Divorce has caused an even larger catastrophe where $9 \mathrm{~m}$ children grow up without fathers (Frazier 2019). The unfortunate reality for most of the children is that $50 \%$ of all fathers in South Africa do not have daily contact with their children (Richter et al. 2010:361). A further negative aspect is that 63\% of reported youth suicides in South Africa originate from fatherless homes (Frazier 2019).

A third of the country's prisoners are young fathers at the age of 18-25 years who have children outside the prison walls. Research has indicated that if children grow up without fathers, factors such as poor educational outcomes and anti-social behaviour may result in disrupted employment (Frazier 2019). Furthermore, certain enhancing factors are directly or indirectly influenced by the presence of the father. These include health, well-being, academic performance, self-confidence and behaviour control in boys and girls (Frazier 2019).

In our country, there is a distinct lack of positive father figures (as role models). Analysts refer to this problem of fatherlessness as a 'terrifying dilemma' and 'corrosion of fatherhood' that destroyed families (Cape Argus 23 June 2008:15; John 2012; Swartz et al. 2013). This corrosion is a major cause of the current societal ills in South Africa, seeing that $30 \%$ of children are born into single-parent homes. In black communities, this figure is even more disturbing, increasing to $68 \%$ (Feni 2016).

As previously mentioned, statistics from 2013 (5.3m) and 2015 (9m) have estimated that $2.13 \mathrm{~m}$ children in South Africa are currently fatherless (Dube 2016). These statistics reveal an immense fatherhood challenge for the country. The figures were released by Statistics South Africa and further indicated that many of these children are left without parents, whilst others are raised by single-parent mothers, 
grandparents, caused by the system of colonialism that destroyed this structure. The survey also found that paternal orphanhood is consistently higher than maternal orphanhood. Orphanhood has also become a critical issue because of the HIV-AIDS pandemic in South Africa where both parents are deceased. Furthermore, the survey indicated that a mere 1651 adoptions were registered during the period of 01 April 2014 to 31 March 2015. This is a critical risk factor in terms of the development of missional fatherhood (Dube 2016).

'South Africa is also rapidly becoming a fatherless society with men behaving like monsters towards women and children'. This was one of the critical statements raised at a forum held in Mthatha in the Eastern Cape, investigating fatherless societies and the decline in fatherhood (Feni 2016; Natal Witness 24 June 2004:16). Furthermore, it was stated that the influence of fathers in families had declined significantly since the beginning of democracy in South Africa. At this forum, men were urged to change as they have the capacity and willpower to reset their boundaries, restore their image and start afresh with renewed values (Feni 2016).

Another detrimental issue that has caused father absence in South Africa was the xenophobic attacks in 2008 where the perpetrators were described as the 'fatherless sons of violence' (Star 25 June 2008:35). During these attacks, numerous people, especially men, were brutally murdered, beaten up, stabbed and raped, and as a result, many children were left fatherless (Hans 2008). Millions of children and adolescents were left without parents, and during this time, South Africa was described as a fatherless society (Cape Argus 23 June 2008:15; Natal Witness 24 June 2004:16). The xenophobia attacks indicated the acute lack of father figures in the fragmented society (Star 25 June 2008:35), therefore the urgent need for missional fatherhood to involve fathers and to build hope within families.

An urgent request to lessen the impact of fatherlessness was made 18 years before the attacks, seeing that millions of South African children have little or no contact with their fathers. The Fatherhood Project by the Human Sciences Research Council (HSRC) at that time (2002) was an initiative to lessen the impact of fatherlessness and encourage the development of social fathers (The Herald 18 April 2002:8).

Psychologists argue that during this time, a lack of adequate parenting caused the behavioural problems amongst the youth. Psychologists further mention that many black men lack the capacity to be a father to their children because their own fathers were absent and deserted them. This situation caused severe family breakdowns and disrupted community structures seeing that young boys and men turned to gangs and crime, which destroyed social structures (Star 25 June 2008:35).

The problem of absent parents, especially during a child's upbringing, is a social dilemma and was highlighted in several local newspapers in South Africa (Fayo 2008). Fatherless children are at a higher risk of substance abuse, mental illness, suicide, poor education and criminality (Feni 2016). It can be an emotional challenge for a child to grow up fatherless or have no father figure at all. Therefore, it is essential that men should develop relationships with their children as fathers and bond with them emotionally (Botha 2013).

In this article, it is essential to understand that fatherless households are a fact within South African society and cannot be ignored any longer. The problem is complex because there are no clear paths or solutions to choose in terms of addressing this detrimental societal problem.

\section{Research problem, research question, objectives, central theoretical argument and research method}

Father absence is a phenomenon that does not only transpire in local communities but also occur worldwide (Dobbs 2013; Freeks 2011; Freeks 2013:3; Williams 2014). Research substantiates the fact that fatherhood is imperative. Regardless of the changing world, fathers still play a unique role in the progress and development of their children's choices, relationships, self-esteem and behaviour (Vaughan 2010; Waresak 2016a, 2016b). This raises the question: to what extent could guidelines be established for effective and involved fathering in the Fatherhood Training and Equipping Programme used to train inmates at a correctional facility? From the introduction and problem statement above, the main research question was formulated: How can missional fatherhood contribute to the father absenteeism dilemma in South Africa?

Researching this question has had the principal aim of assessing the Fatherhood Training and Equipping Programme from a missiological context. This completed assessment focused on the programme's impact and effectiveness at the Potchefstroom Remand Detention Facility in the North West Province, South Africa. To reach this aim, the following objectives were formulated: Firstly, to investigate which guidelines are successful in terms of effective fathering and the role of the missional father; secondly, to assess what personal experiences of inmates (fathers) may be found for effective fathering; thirdly, to train and equip inmates (fathers) to be effective, and to bring about positive change within the family once they are on parole or released from prison. Lastly, the missional connection to the inmates should be a crucial facet of God's mission. The central theoretical argument of the Fatherhood Training and Equipping Programme may provide a possible solution against the afore-mentioned problems facing communities and families. Methodologically, the research was executed using an explorative literature study.

\section{The Fatherhood Training and Equipping Programme and its project: A life beyond iron bars}

The Fatherhood Training and Equipping Programme with its subtitle, 'Dad, become fully you', was developed in 2011 to be used in the field of community engagement and prison 
ministry. The programme was compiled from own research and studies in collaboration with FAMSA (Families South Africa). The programme became one of the strengths and core responsibilities of the research because the main aim thereof was to train and equip fathers and to restore the indispensable role of the father within the family context. In 2015, the same programme with its project, 'A life beyond iron bars', started at the Potchefstroom Remand Detention Facility (previously known as the Potchefstroom Correctional Services). The prison building was erected in 1847 with only 390 prisoners at the time. Currently, the prison accommodates more than 2050 prisoners, including male and female prisoners, before the remission of sentences to offenders was announced and implemented by our President Mr Cyril Ramaphosa (cf. Kgosana 2019:1-5; Veltman 2018).

Although the programme needs a great deal of spirituality, it is unfortunate that spirituality is not the focus of this article.

\section{The aim of the Fatherhood Training and Equipping Programme}

The aim of the programme remains to train and equip, motivate, inspire and empower fathers in prison, according to the following guideline in the White Paper on Corrections in South Africa, Chapter 3, Section 3.3.7): '... creation of an environment in which offenders are encouraged to discard negative and destructive values and replace them with positive and constructive values (Department of Correctional Services 2005)'.

\section{The themes of the Fatherhood Training and Equipping Programme}

The programme consists of seven themes, namely the concept of fathering, self-image, character, labelling, disappointments, the father as developer and dad become fully you. Approximately 250 inmates (fathers) were trained and equipped through the programme from 2015 to 2018. The above action is in fact a good preparation for fathers who will re-enter the community.

\section{The aspect of biblical guidelines as a key factor in the Fatherhood Training and Equipping Programme}

Father absence is a massive challenge in the South African context, and in order to address this challenge, biblical guidelines are crucial for families and communities who are confronted with this growing problem. Biblical guidelines serve as viable solutions to the problem of father absence. Biblical guidelines towards the role of the father are vital within the family and community contexts, and biblical fatherhood should be the basis for dealing with issues such as father absence and understanding the role of the man in the home.

\section{What is missional fatherhood?}

Before discussing what missional fatherhood implies, it is vital to first understand what the concept 'missional' really means and what the theological insights behind the concept are and the link between the Missio Dei, the mission ecclesiae and missional fatherhood?

The concept missional has a true meaning. It is not merely a Christian buzz word or a catch phrase that families can use to act spiritual. The concept 'missional' from the words of Jesus in John 20:21-23: 'Peace be with you, as the Father has sent me, even so I am sending you'. And when he had said this, he breathed on them and said to them, Receive the Holy Spirit. If you forgive the sins of any, they are forgiven; if you withhold forgiveness from any, it's withheld' (cf. also Buys \& Jansen 2015:228). Any Christian's whole life should be a life of being sent to win your neighbour for Christ. There are only two possibilities, one is either a missionary or a missionary object. In Acts 1:8, it says that being filled with the Holy Spirit means witnessing Christ. Hence, the words

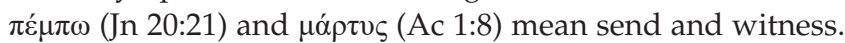
Missio Dei is God's mission (i.e. steering wheel) of his Son and the Holy Spirit to call and empower the people to be his instruments (i.e. hands and feet) and inhabited 'heart of Jesus to be' ... to be blameless children of God in the midst of degenerate and corrupt people and to act as light bearers in the world (cf. Buys \& Jansen 2015:228; Buys 1983:320-328; Rozko 2012; Phlp 2:15). Missiones ecclesiae is the calling of the church and all believers should read texts such as John 20:21; Matthew 28:29; 20; Acts 1: 8; Philippians 2:15 and the like, to live out God's mission and to make it true. This important calling must also happen in every Christian household (Goheen 2011:218). In the context of this article, missional fatherhood imply that the father makes his family and children part of God's great plan (Cousineau 2013; Dube 2016; Greenland 2014; Waresak 2016b). This is the crucial link between the Misso Dei, missiones ecclesiae and missional fatherhood.

The missional fatherhood implies that the father takes on the leading role as a missional father within the family and accepts and follows a specific role. This means to live a sacrificial life for the sake of his family and also cater to the needs of others. The heart and life of this father are committed to a God-given mission and the Fatherhood of God where he models and inculcates the love of Christ into the hearts of his children and also sacrifices his time to help the community (cf. Waresak 2013). The Fatherhood of God has a bearing on our understanding of fatherhood in the family. God's intention is that man (also the father) would reign for God and in life with Christ over all things to express and represent him (cf. Gn 1:26; Eph 1:22-23; Rm 5:17, 21 \& Rm 16:20).

In the Bible, missional fathers can be called 'Micah's fathers', as described in Micah 6:8:

He has told you, O man, what is good; and what does the Lord require of you but to do justice, and to love kindness, and to walk humbly with your God? 
In this context, missional fathers must engage with their children about aspects that matter most in life, such as striving to ensure that their lives glorify God. In other words, these fathers should become preoccupied with the business of God the Father (cf. Rm 12:1; 1 Cor 10:31) (Waresak 2013).

Greenland (2014) indicated that missional fatherhood has four significant ways to ensure its success. They are as follows:

- Parents should shape their children's worldview bitesized. This means the father should expose children to the needs of others in the world, with the motivation to reach a lost and dying world for Christ.

- The father and family should meet the various needs together, for example, experiencing missions jointly as a family.

- A father should convey his passion for missions to the children by discussing it and allowing them to observe his excitement.

- The father must ensure immediate obedience and response from his children in the home in terms of assignments and suggestions. His children are allowed to ask questions or disagree. However, it is vital that they first listen to his ideas, suggestions for doing missions.

The researcher agreed with the afore-mentioned because his recent research is about missional fatherhood, and the research substantiates the mentioned points (cf. Freeks 2018:161-165, 183-193).

According to Cousineau, a missional father shows specific characteristics, and, in this regard, he identifies five essential traits (Cousineau 2013):

Mission is selfless: The father should explain to his family that making disciples should be a selfless undertaking. Furthermore, children must understand that Christ gave himself to others. Fathers should follow this example by living a life focused on others to the glory of the heavenly Father. In this way, fathers teach their children to live and have a heart for mission.

Learn to be broken for others: This means giving, praying and investing more in the lives of other people. It is crucial that children see the father giving to those who are in need and helping out others. A missional father should apply 1 Thessalonians 2:8 in his life as a father: emphasising love for others and giving oneself to others.

Live Christ-focused: It is imperative that children should see their father being overwhelmed by Jesus in his life. The focus and motivation of the father should be on Jesus Christ, and his children should see him serving the Lord.

Be Spirit-led: A father should follow the guidance of the Holy Spirit in all his ways, decisions, advice and lifestyle. He should share with his children the testimony of how the Holy Spirit answers their prayers as a family.
Be generous: He should continually bless other people with the blessing with which Christ has blessed him. This father's time, money and energy should be used to help other people. The researcher suggests that the father encourages his children to adopt an attitude of giving their money, gifts and energy to the church and community.

From the above, it is evident that missional fathers should live for God and other people. They should know that their lives are not their own but a gift and a blessing from God. Such fathers should thus be missionally minded and even disciple-makers in their homes, amongst other families and their respective communities.

\section{Restoring true fatherhood within the family with the assistance of the missional fatherhood approach}

The researcher is convinced that the above-mentioned statistics of father absenteeism can be countered by restoring the role of fathers within the family and re-addressing their true calling as men Coram Deo (in God's presence). These negative statistics and downward trends can be reversed by God as Father through Jesus Christ. God promised, according to Malachi 4:6: 'He (Elijah) will bring fathers and children together again; otherwise I would have to come and destroy your country'.

Fathers should take responsibility for their dysfunctional families, disrupted society and crises in the country as a whole. They should adhere to Scripture and understand and follow God's directive in 2 Chronicles 7:14:

If my people, who are called by my Name, will humble themselves and pray, and seek my face, and turn from their wicked ways; then I will hear from heaven, and will forgive their sin, and will heal their land.

The question thus remains: How can fathers break this sin (of father absenteeism and fatherlessness)? The researcher is of the opinion that the only way for fathers and families to break this vicious circle is by knowing God as Father through Jesus Christ and the work of the Holy Spirit (Smail 1980). This entails faith in the Triune God: The Father sending the Son and both sending the Spirit to restore the rule of the Father over creation (Chandler 2015; Smail 1980).

The way towards restoration is evident. Fathers should seek to know God as Father through Jesus Christ and experience the new birth given by the Holy Spirit through the Word (1 Pt 2). This means new life in them and their families, which will help break the epidemic of fatherlessness (Freeks 2013).

The researcher is also of the firm belief that Jesus Christ is the crucial Answer to the problem of father absenteeism and fatherlessness, seeing that he realises in people a relationship with God the Father. In addition, the Trinitarian perspective, as discussed above, will guide fathers and lead them in the truth of God. 
In this regard, men should understand that such a relationship with the Triune God shows the way to live as fathers in their missional role. This is also the way to solve the fatherhood problem as it exists currently. Fathers have the opportunity to be used by God to impact their family. It is essential for missional parenthood that fathers receive Jesus Christ as their Saviour and become children of God (John 1):

To all who did receive Him, who believed in His Name, He gave the right to become children of God (v. 12),

and

... who were born, not of blood nor of the will of the flesh nor of the will of man, but of God. (v. 13)

No father can be saved and not intentionally seek to build Christ's love and presence into the lives of his family. Therefore, fathers should know that fatherhood is a Godgiven calling. They need to be role models that embody the qualities and missional purpose of Christ's new commandment. In practical life, this implies loving others such as Christ loves them. If fathers succeed in this area, they have fulfilled their calling in life where it matters the most, namely family life (Waresak 2013).

\section{Teaching can be used as a missional instruction for fathers to follow within the family}

The father should play an active role in the life of his children when he teaches them. All processes of life can be considered education as such, and the father must take the lead in the content and life truths which his children are taught. Teaching, however, takes place more through actions than words. Thus, as teacher in the home environment, the father's first priority is to practise what he preaches (Farrar 2003).

God has placed the responsibility on parents, especially the father as the leading figure in the family, to teach their children (Dt 6:1). This responsibility implies taking the initiative to teach, for example, standing firm on a moral foundation. Furthermore, the father should teach children how to deal with temptation and control their anger. If fathers can fulfil such roles, they will help their children embrace a godly life. God wants fathers to lead their children the same way as he leads them as fathers (Farrar 2003).

Teaching children will give them a solid foundation according to which they can succeed in life (Farrar 2003). If fathers teach and train their children in the way they should go, the latter must also involve every practical task of life. Fathers should teach their children from the Word of God and allow them to read for themselves, the guidelines (especially biblical ones) they should know on this life journey. The aim is that the father makes the child part of whatever he teaches or expects the child to do. Benjamin Franklin stated clearly: 'Tell me and I forget, teach me and I may remember, involve me and I learn' (cf. also Pr 14:8).

Proverbs 13:24 says: 'Whoever spares the rod hates his son, but he who loves him is diligent to discipline him'. In this specific scripture, the 'rod' of discipline should be understood as a metaphor for the action of the father as a parent that holds consequences for a child's actions (cf. also Pr 19:18; $22: 15 ; 23: 13-14 ; 29: 15,17 ; \mathrm{Eph} 6: 4 ; \mathrm{Col} 3: 21$ ). If the father disciplines with an attitude of love and self-control, those consequences will be useful and not harmful. Thus, discipline should be understood as a form of teaching by setting boundaries that guide and instil appropriate behaviour (Farrar 2003; Freeks 2013).

Here it is essential to know that discipline does not only refer to physical punishment but also means encouraging children and rewarding them for correct or exemplary behaviour (Farrar 2003; Freeks 2013). The purpose of discipline is, according to Deuteronomy 6:2, firstly to fear God, secondly to instil respect, especially for the father and other authority figures and thirdly to be accountable for personal actions (Clements 2003; Farrar 2003).

\section{Ethical considerations}

The research is executed by means of an explorative and reflective literature study. Training and equipping through community engagement programmes and projects are an important facet at the Faculty of Theology, North-West University in Potchefstroom. Permission was granted by the Head Correctional Chief (HCC) of the Potchefstroom Correctional Services to do the fatherhood training and equipping programme under the inmates (fathers).

\section{Results of the fatherhood training sessions}

It is paramount to take cognisance that some of the findings form an integral part of the central theoretical argument in this article. Inmates (fathers) indicated their tendencies about spiritual matters in the training and equipping sessions as well as in the research. They also mentioned during the training sessions the importance of applying biblical principles in their missional role as a father. This specific point was the whole idea and purpose of the Fatherhood Training and Equipping Programme for inmates (fathers).

\section{Shortcomings of the Fatherhood Training and Equipping Programme and sessions}

The following shortcomings were identified:

- The venue where the fatherhood training and equipping took place caused ample frustrations and difficulties for inmates and many times resulted in arguments and disagreements.

- A lack of effort to spur on inmates to attend the training and equipping sessions posed a severe problem for the presenter as it was disappointing to note that only 38 inmates participated in the feedback sessions after the presentation of the Fatherhood Training and Equipping 
Programme to more than 200 inmates over a period of 3 years.

- A lack of co-operation and support amongst inmates was evident during group discussions in the training sessions as some inmates complained about the negative remarks and statements made about the programme by both their fellow inmates and staff members of the correctional facility.

- The importance of spiritual growth as a spiritual outcome amongst inmates is not only a lack or shortcoming but a great need and concern within the programme.

\section{Recommendations}

- The Fatherhood Training and Equipping Programme should be strongly considered for future research as a proposed solution to the problem of father absence in South Africa.

- It is fundamental to know that God has a higher calling for humans to function as parents. God has not given up on the vital role of the family and, therefore, family life requires the 'proactive impartation of biblical principles'. The role of the family is accentuated within the biblical narrative, and its importance is consistently brought to the attention of God's followers in terms of the crucial missional role of the father within the family.

- Missional fathers should reach a point where they trust fully in the Triune God, God the Father, Jesus Christ the Son, and in the power of the Holy Spirit to lead and govern their families under the authority of the God the Father. This means the solution lies in God through his Son, Jesus Christ with the guidance of the Holy Spirit to deal with father absenteeism.

- The father is God's instrument to lead and model the life and the example God intended him to be for his children. Therefore, the argument is that fatherhood stems from the Bible.

\section{Conclusion}

The father figure within the family has to adopt and implement a strategy of missional fatherhood and apply the Word of God within the home. Using this strategy, the dilemma of father absenteeism should decrease, and healthier families will be seen in communities, societies and, eventually, the entire world. Families should abide in the Word of God and believe that he is faithful and will empower them through his Spirit to solve issues such as father absenteeism and fatherlessness that may occur in the life of a family. The father figure is God's instrument to lead and model the life and the example God intended for him to be. Therefore, the argument is that fatherhood stems from the Bible.

\section{Acknowledgements Competing interests}

The author declares that he has no financial or personal relationships that may have inappropriately influenced him in writing this article.

\section{Authors' contributions}

F.E.F. is the sole author of this research article.

\section{Funding information}

This research received no specific grant from any funding agency in the public, commercial or not-for-profit sectors.

\section{Data availability statement}

Data sharing is not applicable to this article as no new data were created or analysed in this study.

\section{Disclaimer}

The views and opinions expressed in this article are those of the author and do not necessarily reflect the official policy or position of any affiliated agency of the author.

\section{References}

Amoateng, A.Y., Richter, L.M., Makiwane, M. \& Rama, S., 2004, 'Describing the structure and needs of families in South Africa: Towards the development of a national policy framework for families', A report commissioned by the Department of Social Development, Pretoria.

Bartlett, E., 2013, 'Die impak van afwesige vaders op adolessente meisies se psigososiale welstand', Hon BA dissertation, Dept. of Health Sciences, North-West University, Potchefstroom.

Bertelsmann, M., 2016, 'Where have our fathers gone?', Parent24, viewed 09 April 2019, from https://www.parent24.com/Family/Parenting/where-have-ourfathers-gone-20160217-2.

Botha, M., 2013, 'Fatherhood's a struggle for the fatherless', Mail and Guardian, 21 November, 2013, p. 34.

Buys, F., 1983, 'Ons huis ' $n$ poort na Christus en sy gemeente', Venster op die gesin: Openhartige gesprekke met ouers, kinders en familie, pp. 320-328, PU vir $\mathrm{CHO}$, Potchefstroom (Wetenskaplike bydraes van die PU vir $\mathrm{CHO}$. Instituut vir Reformatoriese Studies, Reeks F3: Versamelwerke no. 19).

Buys, P.J. \& Jansen, A., 2015, "With heart and hands and voices": Integral ministry of word and deed from a missio Dei perspective', International Journal of Reformed Theology and Life 1(1-2), 225-250. https://doi.org/10.35285/ ucc1.1-2.2015. art14

Cape Argus, 2008, 'The fatherless sons of violence', Cape Argus, 23 June, 2008, p. 15.

Chandler, D.J., 2015, 'Whole-person formation: An integrative approach to Christian education', Christian Educational Journal 12(2), 314-332. https://doi.org/ education', Christian Education

Clements, R.E., 2003, 'Proverbs', in J.D.G. Dunn \& J.W. Rogerson (eds.), Eerdmans commentary on the Bible, pp. 437-466, W.B. Eerdmans, Grand Rapids, MI.

Cousineau, J., 2013, ' 5 characteristics of a missional father', The Council on Biblical Manhood and Womanhood, viewed 09 April 2019, from https://cbmw.org/topics/ fatherhood/5-characteristics-of-a-missional-father.

Department of Correctional Services, 2005, White paper on corrections in South Africa, Department of Correctional Services, Pretoria.

Dobbs, P., 2013, 'The impact of fatherlessness on the way one relates to God as father', Master's dissertation, Dept. of Theology, University of Otago, Dunedin.

Dube, D., 2016, '2.13 million kids in SA fatherless', New Age, viewed 09 April 2019, from https://www.ann7.com/2-13-million-kids-in-sa-fatherless/.

Farrar, S., 2003, 'Seven steps for effective fathering', LifeWay, viewed 10 September 2019, from https://www.lifeway.com/Article/Seven-steps-for-effective-fathering.

Fayo, S., 2008, 'Does a fatherless gap motivate men to pursue political struggle?', Herald, 30 December, 2008, p. 4.

Feni, L., 2016, 'Forum raises concern over fatherless society', Daily Dispatch, 21 March, p. 2.

Ford, J., Nalbone, D., Wetchler, J.L. \& Sutton, P.M., 2008, 'Fatherhood: How differentiation and identity status affect attachment to children', American Journa of Family Therapy 36(4), 284-299. https://doi.org/10.1080/01926180701647074

Frazier, T., 2019, 'The result of fatherlessness in South Africa', Tumi Frazier, viewed 09 April 2019, from https://www.tumifrazier.com/fatherlessness-in-south-africa.

Freeks, F.E., 2008, Manual for course facilitators: LIFEPLAN ${ }^{\circledast}$, AUTHeR (Africa Unit for Trans-disciplinary Health Research), North-West University, Potchefstroom.

Freeks, F.E., 2011, 'The role of the father as mentor in the transmission of values: A pastoral-theological study', PhD thesis, Faculty of Theology, North-West University, Potchefstroom.

Freeks, F.E., 2013, Dad is destiny: The man God created to be, Ivyline Technologies, Potchefstroom. 
Freeks, F.E., 2016, 'Die noodsaak van Skrifgefundeerde vaderskap as antwoord op die voortslepende probleem van vaderskapafwesigheid in Suid-Afrika', Tydskrif vir Christelike Wetenskap 52(1 \& 2), 1-27.

Freeks, F.E., 2018, 'A Missional evaluation of the LIFEPLAN ${ }^{\circledR}$ Training and Equipping Programme for youth in rural areas: A case study of its impact in the Christiana district of South Africa', PhD thesis, Faculty of Theology, North-West University, Potchefstroom.

Goheen, M.W., 2011, A light to the nations: The missional church and the biblical story Baker Academic, Grand Rapids, MI.

Greenland, S., 2014, 'Missional fatherhood: Four ways to make every moment count', The Church, viewed 09 April 2019, from https://message.thechurch.at/blog/ 2014/06/11 missional-fatherhood-four-ways-to-make-every-moment-count.

Hans, B., 2008, 'Local children left fatherless', Witness, viewed 09 April 2019, from https:// www.news24.com/archives/witness/local-children-left-fatherless-20150430.

Hawkins, C., 2015, 'Most SA households run by single moms', SA Breaking News, viewed 09 April 2019, from https://www.sabreakingnews.co.za/2015/09/03/ most-sa-households-run-by-single-moms/.

John, V., 2012, 'Fatherless children find their voices', Mail \& Guardian, 21 June, p. 24.

Kgosana, R., 2019, 'Ramaphosa grants remission of sentences to offenders for Reconciliation Day', The Citizen, viewed 06 February 2020, from https://citizen. co.za/nwes/south-africa/crime/2219534/ramaphosa-grants-remission-ofsentences-to-offenders-for-reconciliation-day/.

Linn, J.G., Wilson, D.R. \& Fako, T.T., 2015, 'Historical role of the father: Implications for childbirth education', International Journal of Childbirth Education 30(1), 12-18.

Meintjies, H. \& Hall, K., 2013, 'Demography of South Africa's children', in L. Berry, L. Biersteker, A. Dawes, L. Lake \& S. Smith (eds.), South African child gauge, pp. 86-89, University of Cape Town Children's Institute, Cape Town.

Mkhize, V., 2013, 'Black young, poor and fatherless', Star, 19 November, 2013, p. 2.

Natal Witness, 2004, 'Lessening the impact of fatherlessness', Natal Witness, 24 June, 2004, p. 16.

Ratele, K., Shefer, T. \& Clowes, L., 2012, 'Talking South African fathers: A critical examination of men's contributions and experiences of fatherhood and fatherlessness', South African Journal of Psychology 42(4), 553-563. https://doi.org/ 10.1177/008124631204200409

Richter, L., Desmond, C., Hosegood, V., Madhavan, S., Makiwane, M., Makusha, T. et al., 2012, 'Fathers and other men in the lives of children and families', pape presented at the strategies to overcome poverty and inequality: Towards Carnegie III conference, University of Cape Town, 3-7 September.
Richter, L., Chikovore, J. \& Makusha, T., 2010, 'The status of fatherhood and fathering in South Africa', Childhood Education 86(6), 360-365. https://doi.org/ fathering in South Africa', Childhood
10.1080/00094056.2010.10523170

Rozko, J.R., 2012, 'Toward a mission-shaped vision of theological formation: Implications of the missio Dei for theological education', paper given at the American Society of Missiology annual conference, Techny Towers, IL, 15-17th American Society of Missiology annual conference, Techny Tower
June, viewed 08 February 2020, from www.asmweb.org/assets.

Smail, T.A., 1980, The forgotten father: Rediscovering the heart of the Christian Gospel, SCM Press, Sydney.

Star, 2008, 'The fatherless sons of violence', Star, 25 June, 2008, p. 35.

Swartz, S., Bhana, A., Richter, L. \& Versfeld, A., 2013, 'Promoting young fathers' positive involvement in their children's lives', Report, Human Sciences Research Council, Pretoria.

The Herald, 2002, 'EC-Mayor concerned over fatherless kids', The Herald, 18 April, 2002, p. 8.

Trethowan, A., 2008, 'Mentoring, a better way of supporting young people through the leaving care process', Developing Practice 22(Summer), 21-24.

Tyatya, K., 2015, 'It takes a village to raise a child', MyNews24, viewed 09 April 2019, from https://www.news24.com/MyNews24/It-takes-a-village-to-raise-achild-20150921.

Vaughan, J., 2010, 'Dads and the daughters they love', Focus on the Family, viewed 30 September 2019, from https://www.focusonthefamily.ca/parenting/fatherhood/ dads-and-the-daughters-they-love.

Veltman, N., 2018, Welcome to Potchefstroom Correctional Centre: History [e-mail], 27 July 2018.

Waresak, J.T., 2013, 'Missional fatherhood', Dr James Dobson's family talk, viewed 09 April 2019, from https://www.drjamesdobson.org/blogs/the-fatherhoodchallenge/the-fatherhood-challenge/2013/11/11/missional-fatherhood.

Waresak, J.T., 2016a, ' 5 keys to lead your wife, i.e. "wear the pants"', Dr James Dobson's family talk, viewed 30 September 2019, from https://www. drjamesdobson.org/blogs/the-fatherhood-challenge/the-fatherhood-challenge/ 2016/06/22/5-keys-to-lead-your-wife-ie-wear-the-pants.

Waresak, J.T., 2016b, 'Missional fatherhood' in Dr James Dobson's family talk, viewed 30 September 2019, from https://www.drjamesdobson.org/blogs/the-fatherhoodchallenge/the-fatherhood-challenge/2013/11/11/missional-fatherhood.

Williams, R.B., 2014, 'The male identity crisis and the decline of fatherhood', Psychology Today, viewed 30 September 2019, from https://www.psychologytoday.com/ em/152400 